\title{
Diálogo das fontes e soluções de antinomias na efetivação da partilha de quotas por ex- cônjuge ou ex-companheiro de sócio
}

\author{
Dialogue of sources and solutions of antinomies in executing the division of ownership \\ interests by a member's ex-spouse or partner
}

Lucas Salles Moreira Rocha*

Tereza Cristina Monteiro Mafra**

\section{REFERÊNCIA}

ROCHA, Lucas Salles Moreira; MAFRA, Tereza Cristina Monteiro. Diálogo das fontes e soluções de antinomias na efetivação da partilha de quotas por ex-cônjuge ou ex-companheiro de sócio. Revista da Faculdade de Direito da UFRGS, Porto Alegre, n. 42, p. 96-122, abr. 2020. DOI: $<$ https://doi.org/10.22456/0104-6594.77534>.

\section{RESUMO}

O presente artigo objetiva examinar o direito patrimonial do ex-cônjuge ou ex-companheiro de sócio sobre quotas de sociedade limitada, nos casos de rompimento da relação familiar em que haja litígio quanto à divisão dos bens. A matéria atualmente gera controvérsias, pois o art. 600, parágrafo único, do Código de Processo Civil, e o art. 1.027 do Código Civil, que regulam os direitos do ex-cônjuge ou ex-companheiro de sócio nos casos de término da relação conjugal, aparentam conflitar entre si. Diante das controvérsias que permeiam o tema, buscar-se-á, pelo método exploratório, realizar interpretação sistemática e teleológica, para sugerir a aplicação da teoria do diálogo das fontes na compatibilização das normas aparentemente conflitantes.

\section{PALAVRAS-CHAVE}

Divórcio. Partilha de quotas. Diálogo das fontes.

The purpose of this article is to examine the property rights of a member's former spouse or partner towards the ownership interests of a limited liability company, in the event of a break in the family relationship, in which there is a dispute over de division of goods owned by the couple. The matter is currently controversial, since Articles 600, sole paragraph, of the Code of Civil Procedure, and Article 1,027 of the Civil Code, which regulate the rights of the former spouse or partner of partners in cases of termination of the conjugal relationship, appear to conflict with each other. Given the controversies that permeate this field, this paper will seek to perform systematic and teleological interpretation, though the exploratory method, in order to suggest the application of the theory of the dialogue of the sources in the compatibilization of the apparently conflicting rules.
\end{abstract}

\section{KEYWORDS}

Divorce. Division of ownership Interests. Dialogue of the sources.

\section{SUMÁRIO}

1. Introdução. 2. Disposições legais aplicáveis à partilha de quotas da sociedade limitada por ex-cônjuge ou excompanheiro de sócio. 3. Conflito e coordenação de normas: métodos de solução de antinomias e a teoria do diálogo das fontes. 4. Diálogo das fontes na efetivação da partilha de quotas da sociedade limitada. 5. Conclusão. Referências. Dados da publicação.

\footnotetext{
* Mestre em Direito pela Faculdade de Direito Milton Campos (FDMC), pós-graduado em Direito Corporativo pelo Instituto Brasileiro de Mercado de Capitais (IBMEC-MG), graduado em Direito pela Faculdade de Direito Milton Campos (FDMC).

** Doutora e Mestre pela Universidade Federal de Minas Gerais (UFMG). Professora da graduação e pósgraduação na Faculdade de Direito Milton Campos (FDMC).
} 


\section{INTRODUÇÃO}

A sociedade limitada é o tipo societário mais escolhido pelo empresariado nacional. Basta ver que, apenas no ano de 2015, foram constituídas, em todo o Brasil, 210.101 sociedades limitadas, contra apenas 2.355 sociedades anônimas (DREI, 2015). Concomitantemente, a comunhão parcial é o regime supletivo de bens no casamento $(\mathrm{CC} / 02$, art. 1.640), sendo aplicável, ainda, à união estável, salvo contrato escrito em contrário $(\mathrm{CPC} / 15$, art. 1.725).

Significa dizer que, em regra, o sócio de sociedade limitada casado pela comunhão parcial de bens, ou em união estável (ressalvada eventual formalização de contrato), deverá, em caso de rompimento do vínculo familiar, partilhar as quotas sociais adquiridas na constância da relação, com seu ex-cônjuge ou ex-companheiro. No caso de casamento pela comunhão universal (antigo regime supletivo do casamento), as quotas sequer têm de ser adquiridas na constância da relação, para que possam ser objeto de partilha decorrente de meação.

A convergência de fatos demonstrada acima somada ao crescente número de divórcios que vêm ocorrendo no Brasil ${ }^{1}$, especialmente após o advento da Emenda Constitucional n. 66 de 2010, demonstra a importância do tema concernente à partilha de quotas da sociedade limitada em caso de rompimento de relação conjugal submetida a regime que determine a comunicação de bens.

Não obstante a relevância da matéria, ainda existe uma profunda insegurança jurídica acerca dos direitos que o ex-cônjuge ou ex-companheiro de sócio possui em face deste e da sociedade limitada- e acerca dos procedimentos adequados à efetivação do direito à meação respectiva. Por um longo período de tempo, os juízes e tribunais pátrios enfrentaram a difícil tarefa de interpretar o obscuro art. 1.027 do $\mathrm{CC} / 02$, que, à primeira vista, sobreleva demasiadamente a preservação da empresa. Diversos foram os entendimentos, nunca se tendo alcançado, entretanto, consolidação interpretativa.

Com o fito de contribuir para a solução do impasse, o CPC/15, no art. 600, parágrafo único, trouxe disposição expressa, legitimando o ex-cônjuge ou ex-companheiro de sócio a

\footnotetext{
1 De acordo com as Estatísticas do Registro Civil 2013, publicadas pelo Instituto Brasileiro de Geografia e Estatística - IBGE (IBGE, 2013), ao longo do ano de 2014, foram formalizados, no Brasil, 254.251 divórcios, tendo ocorrido, no mesmo ano, 1.052 .477 registros de casamento, ou seja, uma proporção média de aproximadamente 1 divórcio para cada 5 casamentos. Disponível em: $<$ http://www.ibge.gov.br/home/estatistica/populacao/registrocivil/2013/default_xls.shtm>. Acesso em: 07 fev. 2017.
} 
requerer a apuração de haveres da sociedade limitada, em caso de término da relação conjugal. O enunciado introduzido, todavia, aparenta conflitar com o art. 1.027 do $\mathrm{CC} / 02$, que restringe os direitos do meeiro à percepção dos lucros da sociedade, até que seja promovida a liquidação desta.

Tradicionalmente, o conflito entre os dispositivos seria resolvido pela aplicação dos métodos de solução de antinomias, que resultam na revogação ou derrogação de um dos preceitos normativos. O presente artigo buscará, entretanto, demonstrar a possibilidade de aplicação da teoria do diálogo das fontes à hipótese, em detrimento dos métodos de soluções de antinomias, para demonstrar que o art. 600, parágrafo único, do $\mathrm{CPC} / 15$, não revogou, ou derrogou, o art. 1.027 do CC/02, podendo tais dispositivos existir harmonicamente.

Além da introdução e da conclusão, o estudo está organizado em três tópicos. No primeiro deles, tratar-se-á dos dispositivos legais aplicáveis à partilha de quotas da sociedade limitada por ex-cônjuge ou ex-companheiro de sócio. No próximo item são explorados os tradicionais métodos de solução de antinomias e a teoria do diálogo das fontes. No item seguinte, o estudo versa sobre a satisfação dos direitos do ex-cônjuge ou ex-companheiro de sócio, sob a ótica da teoria do diálogo das fontes, que constitui o marco teórico adotado no presente estudo.

\section{DISPOSIÇÕES LEGAIS APLICÁVEIS À PARTILHA DE QUOTAS DA SOCIEDADE LIMITADA POR EX-CÔNJUGE OU EX-COMPANHEIRO DE SÓCIO}

$\mathrm{O}$ art. 1.027 do CC/02, que disciplina os direitos do ex-cônjuge de sócio sobre quotas submetidas à partilha de bens em decorrência de término da relação conjugal ${ }^{2}$, determina que aquele não pode exigir, desde logo, a parte que lhe cabe na quota social, mas pode concorrer à divisão periódica de lucros, até que se liquide a sociedade. Muito embora tenha, aparentemente, traçado de forma bastante clara os direitos do ex-cônjuge perante a sociedade, no sentido de fazer jus tão somente à divisão periódica de lucros, o dispositivo, desde a sua origem, tem sido objeto de controvérsias doutrinárias e jurisprudenciais.

Em comentários ao citado dispositivo, José Waldecy Lucena chega a aconselhar ao sócio que liquide desde logo a parte da quota social incluída na meação, pagando ao meeiro os

2 Embora o art. 1.027 do CC/02 faça alusão somente ao cônjuge do que se separou judicialmente, está claro que o legislador não quis excluir o divorciado, o ex-companheiro ou aquele que teve o casamento nulo ou anulável, mas declarado putativo, pois todos eles têm direito à partilha de bens. Trata-se de uma omissão que pode perfeitamente ser suprida pela analogia (art. $4^{\circ}$ da LINDB). 
haveres correspondentes, eis que a continuidade do recebimento de lucros até que se liquide a sociedade é fonte perene de dissenções, de disputas, de desconfianças, que podem abalar e perturbar a vida societária (LUCENA, 2005, p. 951-952).

Em decisão proferida em 19/02/2001, ou seja, pouco antes do advento do CC/02, o STJ, ao julgar o REsp n. 114.708/MG, de relatoria do Min. Waldemar Zveiter, fixou entendimento no sentido de ser possível tanto a apuração de haveres da sociedade por cotas por parte do excônjuge de sócio, quanto o seu ingresso na sociedade, caso haja permissão no contrato:

RECURSO ESPECIAL. SOCIEDADE POR COTAS. DISSOLUÇÃO E LIQUIDAÇÃO. SEPARAÇÃO JUDICIAL. PARTILHA. AFFECTIO SOCIETATIS. 1. O cônjuge que recebeu em partilha a metade das cotas sociais tem legitimidade ativa para apurar os seus haveres. 2. Hipótese, ainda, em que o Tribunal a quo, interpretando o contrato, entendeu que o cônjuge meeiro pode ingressar na sociedade. [...] (BRASIL, 2001)

Segundo Rachel Sztajn, o CC/02, de forma lamentável, contrariou jurisprudência que vinha se consolidando a respeito da matéria, com o objetivo de afastar a possibilidade de dissolução parcial da sociedade limitada pelo ex-cônjuge de sócio:

O códex recém-promulgado, ao que tudo indica, procurou evitar a dissolução parcial pleiteada pelo ex-cônjuge de sócio ou herdeiros deste. Afirma-se que a referida norma preserva a empresa, impedindo que herdeiros do cônjuge de sócio, ou cônjuge separado judicialmente, busquem o recebimento da parcela que eventualmente lhes caiba no patrimônio da sociedade, por força da quota parte do sócio falecido. ${ }^{3}$ Ou seja, o artigo veda, aos herdeiros do cônjuge de sócio e ao exconsorte de sócio, o direito de pleitear o pagamento dos haveres correspondentes à participação societária havida por meação ou herança. A eles confere, como se depreende da leitura do texto legal, apenas e tão somente o direito de receber os dividendos: nenhum outro mais. Àquelas pessoas, com efeito, não outorga o novo Código Civil o direito de votar, de fiscalizar a gestão da sociedade, etc. (FONSECA; SZTAJN, 2008, p. 344)

$\mathrm{Na}$ esteira da norma de direito material que restringiu os direitos do ex-cônjuge de sócio em relação às quotas da sociedade limitada, parte da jurisprudência passou a julgar improcedentes os pedidos de dissolução parcial e apuração de haveres realizados por excônjuge de sócio. É o que se extrai das decisões proferidas pelo TJMG e TJSP, respectivamente, na Apelação Cível 2.0000.00.474595-9/000, de relatoria do Des. Mauro Soares de Freitas, e na Apelação Cível 0123702-08.2008.8.26.0000, de relatoria do Des. Erickson Gavazza Marques:

APELAÇÃO CÍVEL - DISSOLUÇÃO E LIQUIDAÇÃO PARCIAL DE SOCIEDADE MERCANTIL - EX-MULHER DO SÓCIO - ILEGITIMIDADE OBJETIVO - PARTILHA DE BENS - PROCEDIMENTO INADEQUADO SENTENÇA MANTIDA. Em regra, somente podem demandar aqueles que forem sujeitos da relação jurídica de direito material trazida a juízo. Cada um deve propor

3 "A partilha em questão não poderá ter como objeto as quotas detidas pelo sócio na sociedade, mas apenas o direito à percepção dos lucros que ao sócio falecido ou separado tocarem" (FIUZA, Ricardo. Novo Código Civil comentado. São Paulo: Saraiva, 2002, p. 924). 
as ações relativas aos seus direitos. Salvo casos excepcionais expressamente previstos em lei, quem está autorizado a agir é o sujeito da relação jurídica discutida. Assim, quem pode propor a ação de cobrança de um crédito é o credor, quem pode propor a ação de despejo é o locador, quem pode pleitear a reparação de dano é aquele que o sofreu. Portanto, não constando como sócia da sociedade e objetivando a partilha de bens do casal é a autora parte ilegítima para pleitear a dissolução e liquidação parcial da sociedade, além de escolher o procedimento impróprio para partilhar os bens em nome da sociedade. (grifo nosso) (MINAS GERAIS, 2006)

SOCIEDADE POR COTAS DE RESPONSABILIDADE LIMITADA APURAÇÃO DE HAVERES E DISSOLUÇÃO PARCIAL DA EMPRESA CÔNJUGE QUE ADQUIRIU COTAS EM RAZÃO DA DISSOLUÇÃO DE SEU CASAMENTO COM UM DOS SÓCIOS CIRCUNSTÂNCIA QUE NÃO A TORNA SÓCIA DE SOCIEDADE INTUITO PERSONAE CUJO ELEMENTO É O AFFECTIO SOCIETATIS CARÊNCIA DA AÇÃO BEM DECRETADA DIREITO DE PERCEPÇÃO DOS LUCROS E DIVIDENDOS. [...] Sociedade por cotas de responsabilidade limitada - apuração de haveres e dissolução parcial da empresa cônjuge que adquiriu cotas em razão da dissolução de seu casamento com um dos sócios - circunstância que não a torna sócia de sociedade intuito personae cujo elemento é o affectio societatis - carência da ação bem decretada - direito de percepção dos lucros e dividendos deve ser perseguida em procedimento próprio sentença de extinção sem resolução do mérito mantida - recurso não provido. (grifo nosso) (SÃO PAULO, 2013)

Não obstante, grande parte da jurisprudência vem afastando a aplicabilidade do art. 1.027. Há hipóteses em que são deferidas, além da apuração de haveres, a dissolução parcial da sociedade, a pedido do ex-cônjuge. É o que se infere das decisões proferidas pelo TJSP na Apelação 0010761-14.2012.8.26.0344, de relatoria do Des. Tasso Duarte de Melo- e Apelação 1013769-49.2014.8.26.0008, de relatoria do Des. Francisco Loureiro, respectivamente:

DISSOLUÇÃO PARCIAL DE SOCIEDADE. Quotas sociais partilhadas em ação de separação judicial. Aplicação literal do art. 1.027 do Código Civil. Inadmissibilidade. Apelante que tem o direito de receber o valor patrimonial das cotas partilhadas. Preservação do direito constitucional de propriedade e do direito fundamental de acesso à Justiça. Precedente do C. STJ. Legitimidade ativa da Apelante reconhecida. Decreto de extinção afastado. Recurso provido. (grifo nosso) (SÃO PAULO, 2014)

DISSOLUÇÃO DE SOCIEDADE C/C APURAÇÃO DE HAVERES - Pedido formulado pela autora em face do ex-marido e da sociedade que integravam foi corretamente acolhido pela sentença - Inexistência de falta de interesse de agir, ou de coisa julgada, a impedir o deferimento do pleito - Mera partilha universal de bens decretada na ação anterior em que litigaram as partes não impede a propositura da presente, com vistas a dissolver efetivamente a sociedade - Ausência de inconformismo do apelante quanto aos termos da dissolução decretada pelo Juízo a quo, que fica integralmente mantida - Recurso não provido. (grifo nosso) (SÃO PAULO, 2016)

É que a aplicação literal do art. 1.027 resulta, muitas vezes, na impossibilidade de o cônjuge meeiro receber a parte que lhe cabia na partilha. Com efeito, não apenas o direito constitucional de propriedade do ex-cônjuge estaria sendo violado, mas também princípios norteadores do direito pátrio, como o da inafastabilidade da prestação da tutela jurisdicional, 
da livre associação e o de acesso à justiça. Sob a ótica da sociedade, estar-se-ia, a partir da restrição dos direitos do meeiro, respeitando os princípios da função social e preservação da empresa, além do direito de sigilo de suas escriturações e livros contábeis ${ }^{4}$.

Em meio aos dissídios interpretativos contextualizados acima, o CPC/15 introduziu no ordenamento jurídico uma inovação acerca do tema, no art. 600, parágrafo único. Nos termos da nova disposição, o ex-cônjuge ou ex-companheiro de sócio pode pleitear, em caso de término da relação familiar, a apuração de seus haveres na sociedade, os quais deverão ser pagos à conta da quota social titulada pelo sócio. Mencionado dispositivo, entretanto, enseja dúvidas. Isto porque o preceito normativo em comento aparenta conflitar com o art. 1.027 do $\mathrm{CC} / 02$, conforme se infere da tabela comparativa abaixo:

\begin{tabular}{|l|l|}
\hline \multicolumn{1}{|c|}{ CPC/15 } & \multicolumn{1}{|c|}{$\mathbf{C C / 0 2}$} \\
\hline $\begin{array}{l}\text { Determina que o ex-cônjuge ou ex-companheiro de } \\
\text { sócio poderá apurar os haveres da sociedade } \\
\text { limitada, em caso de término da relação familiar. }\end{array}$ & $\begin{array}{l}\text { Determina que o ex-cônjuge de sócio deverá } \\
\text { concorrer à divisão periódica dos lucros da } \\
\text { sociedade limitada, em caso de separação judicial. }\end{array}$ \\
\hline $\begin{array}{l}\text { Determina que os haveres apuras deverão ser } \\
\text { pagos à conta da quota social do sócio cuja relação } \\
\text { familiar terminou. }\end{array}$ & $\begin{array}{l}\text { Determina que o ex-cônjuge não pode exigir, desde } \\
\text { logo, a parte que lhe couber na quota social, mas } \\
\text { aguardar até que se proceda à liquidação da } \\
\text { sociedade. }\end{array}$ \\
\hline
\end{tabular}

Fonte: elaborado pelo autor (2017).

Diante do impasse apresentado, buscar-se-á, adiante, traçar uma breve exposição acerca dos métodos de soluções de antinomias e da teoria do diálogo das fontes, para, ao fim, apresentar argumentos contrários à revogação ou derrogação de um dos dispositivos em detrimento do outro- e sugerir interpretação sistemática e teleológica a ser dada aos preceitos legais em comento. No caso, buscar-se-á contribuir para a satisfação dos direitos constitucionais de propriedade, acesso à justiça e livre associação do ex-cônjuge ou excompanheiro de sócio, sem deixar de observar a necessidade de se respeitar os princípios da função social e preservação da empresa.

\footnotetext{
4 Não obstante, com relação ao sigilo fiscal, o próprio CC/02, no art. 1.191, autoriza o juiz a determinar a apresentação de documentos sigilosos, tais como escriturações e livros contábeis, notadamente para resolver questões relacionadas à comunhão.
} 
3 CONFLITO E COORDENAÇÃO DE NORMAS: MÉTODOS DE SOLUÇÃO DE ANTINOMIAS E A TEORIA DO DIÁLOGO DAS FONTES

O conflito entre normas, ainda que aparente, pressupõe a existência de um sistema jurídico, composto por diferentes searas e instâncias que se comunicam entre si. As normas, portanto, não devem ser analisadas de forma isolada, mas interpretadas em consonância com um conjunto que integra o sistema jurídico- e com os princípios que norteiam os fundamentos gerais de direito. A respeito do tema, pertinentes os ensinamentos de Geraldo Ataliba:

\begin{abstract}
De nada vale o conhecimento de uma seara, se se desconhece a sua articulação com as demais. De pouco vale a familiaridade com certas informações, se não se as concatena com o universo do direito, se não se sabe filiá-las, explica-las e concatena-las com os fundamentos em geral e com o todo sistemático onde inseridas. É inútil o conhecimento que se limita à superfície dos fenômenos jurídicos, sem buscar penetrar seus fundamentos explicativos e justificativos. (ATALIBA, 1997, p. 17-18)
\end{abstract}

Reconhecida a possibilidade de haver contradições entre normas integrantes de um mesmo sistema jurídico, mostra-se pertinente a realização de uma breve análise acerca dos métodos que podem ser utilizados pelo intérprete na aplicação de normas que, à primeira vista, mostram-se incompatíveis. Para tanto, far-se-á, adiante, uma breve análise acerca dos métodos de solução de antinomias, bem como da teoria do diálogo das fontes, para posteriormente sugerir interpretação ao art. 1.027 do CC/02 e art. 600, parágrafo único, do $\mathrm{CPC} / 15$.

\title{
2.1 Solução de antinomias jurídicas
}

Tradicionalmente, os conflitos de normas são conceituados como antinomias jurídicas, as quais, nas lições de Tércio Sampaio Ferraz Jr., podem ser entendidas como:

[...] a oposição que ocorre entre duas normas contraditórias (total ou parcialmente), emanadas de autoridades competentes num mesmo âmbito normativo que colocam o sujeito numa posição insustentável pela ausência ou inconsistência de critérios aptos a permitir-lhe uma saída nos quadros de um ordenamento dado. (FERRAZ JR., 1978. p. 14)

As antinomias são classificadas pela doutrina em antinomias reais e antinomias aparentes. Ter-se-á a antinomia real quando houver oposição total ou parcial entre duas ou mais normas contraditórias, emanadas de autoridades competentes num mesmo âmbito normativo, que colocam o sujeito numa posição insustentável pela ausência ou inconsistência de critérios aptos a permitir-lhe uma saída nos quadros de um ordenamento dado (DINIZ, 
2010, p. 92). Do ponto de vista do intérprete, a solução de uma antinomia real reside, portanto, na aplicação de mecanismos para solução de lacunas de conflito, ou seja, dever-se-á aplicar a analogia, os costumes- e os princípios de direito, sempre atendendo aos fins sociais da lei ${ }^{5}$.

A antinomia aparente, por seu turno, ocorrerá quando puder ser resolvida por meio da aplicação de normas que façam parte do sistema jurídico, ou seja, por meio da observância de regras que regulamentem a interpretação normativa.

Os critérios clássicos para solução de antinomias (aparentes) no direito se expressam por três preceitos básicos: cronológico, de especialidade e hierárquico. Assim: a) lei posterior derroga a anterior (lex posterior derogat legi priori); b) lei especial derroga a geral (lex specialis derogat legi generali); e um terceiro afeto à própria validade do direito, critério de hierarquia que expressa a exigência de conformidade entre a lei inferior e a lei superior: c) lei superior prefere à inferior (lex superior derogat legi inferiori) (BOBBIO, 1994, p. 93-96). Estes critérios estão, em parte, previstos no art. $2^{\circ}$ da Lei de Introdução às Normas do Direito Brasileiro ${ }^{6}$.

Podem existir, entretanto, as denominadas antinomias de segundo grau, ou seja, antinomias de antinomias, caso em que os critérios para solução interpretativa conflitam entre si. Neste caso, a regra geral é de que deve prevalecer, primeiramente, o critério hierárquico, seguido da especialidade e, por último, a cronologia. Assim, havendo conflito entre critérios hierárquico e cronológico, ou hierárquico e especial, prevalece a norma hierarquicamente superior. Da mesma forma, havendo conflito entre critérios de especialidade e cronológico, prevaleceria o critério da especialidade. Importante ressalvar, entretanto, que estas regras não são absolutas, podendo haver exceções.

Considerando que as normas antinômicas são, a princípio, válidas, os mecanismos para solução destas, pelo método tradicional, poderão ser utilizados pela revogação tácita, total (ab-rogação) ou parcial (derrogação), de uma, ou ambas as normas. Importante frisar, todavia, que a revogação de norma antinômica pela via interpretativa não soluciona a questão

\footnotetext{
5 BRASIL. Decreto-Lei 4.657, de 04 de setembro de 1942. Lei de Introdução às normas do Direito Brasileiro. Art. 4ํㅡㄴ Quando a lei for omissa, o juiz decidirá o caso de acordo com a analogia, os costumes e os princípios gerais de direito. Art. $5^{\circ} \mathrm{Na}$ aplicação da lei, o juiz atenderá aos fins sociais a que ela se dirige e às exigências do bem comum.

6 BRASIL. Decreto-Lei 4.657, de 04 de setembro de 1942. Lei de Introdução às normas do Direito Brasileiro. Art. $2^{\circ}$ Não se destinando à vigência temporária, a lei terá vigor até que outra a modifique ou revogue. $\S 1^{\circ} \mathrm{A}$ lei posterior revoga a anterior quando expressamente o declare, quando seja com ela incompatível ou quando regule inteiramente a matéria de que tratava a lei anterior. $\S 2^{-}$A lei nova, que estabeleça disposições gerais ou especiais a par das já existentes, não revoga nem modifica a lei anterior. § 3ํㅗㄴ Salvo disposição em contrário, a lei revogada não se restaura por ter a lei revogadora perdido a vigência.
} 
de forma definitiva, mas apenas naquele caso sub judice, pois as normas conflitantes continuarão a existir no sistema jurídico. Para solução evidente da questão relacionada à antinomia de normas, seria necessário, portanto, a edição de lei que pacificasse a controvérsia.

Conforme se infere da breve exposição realizada, os métodos de solução de antinomias tradicionais são afetos à mera validade formal do direito, sem adentrar em seu caráter valorativo, ou em seus princípios norteadores. Entretanto, a atividade jurisprudencial, para responder à complexidade dos fatos sociais e das normas que os regulam, associa-se, em grande medida, à identificação de valores jurídicos, e, embora aos princípios não se subsumam situações de fato, estes devem ser concretizados servindo como fundamento e diretriz do sistema e suas normas, critérios de interpretação e aplicação do direito (MIRAGEM, 2012. p. 73-74).

Nesse sentido, os métodos tradicionais de solução de antinomias mostram-se insuficientes ao atendimento da demanda da sociedade, eis que são meramente formais- e não adentram nas questões que tocam o efetivo interesse social. Diante deste contexto, o professor alemão Erik Jayme, da Universidade de Heidelberg, desenvolveu a teoria do diálogo das fontes, a qual, de forma mais humanista, busca coerência entre normas conflitantes, ao invés de mútua exclusão entre estas. Claudia Lima Marques, citando o professor Erik Jayme, esclarece:

Os direitos humanos, os direitos fundamentais e constitucionais, os tratados, as leis e códigos, 'estas fontes todas não mais se excluem, ou não mais se revogam mutuamente; ao contrário, elas 'falam' uma às outras e os juízes são levados a coordenar estas fontes 'escutando' o que as fontes 'dizem' (MARQUES, 2012. p. 18-19)

Buscar-se-á, portanto, tecer algumas considerações acerca da teoria do diálogo das fontes, para, posteriormente, sugerir interpretação a ser dada aos dispositivos legais que tratam da partilha de quotas da sociedade limitada.

\subsection{Diálogo das fontes e coerência normativa}

A expressão diálogo das fontes deriva de expressão cunhada no direito internacional pelo professor Erik Jayme, em seu curso de direito internacional na Academia de Haia, em 1995. No Brasil, a teoria repercutiu a partir dos estudos desenvolvidos pela professora Cláudia Lima Marques. Analisando a complexidade da realidade fática sobre a qual incidem as normas do direito internacional privado, em especial considerando o direito à identidade 
cultural no contexto da sociedade globalizada, identifica a pluralidade de fontes jurídiconormativas e a necessidade de sua coordenação pelo intérprete (MIRAGEM, 2012. p. 74).

A teoria em comento representa uma verdadeira mudança de paradigma no que tange à interpretação normativa. Isso, pois, superando os tradicionais métodos de solução de antinomias, a teoria busca não uma exclusão recíproca de normas aparentemente conflitantes, mas a coerência entre estas. No caso, o método em apreço tem como preceito os valores e princípios constitucionais e os direitos humanos em geral, de modo a favorecer o lado mais frágil da relação (MIRAGEM; BRONZATTI, 2017, p. 207-229). De acordo com Cláudia Lima Marques, a teoria do diálogo das fontes foi recepcionada pelo direito brasileiro:

É possível afirmar que hoje, sem sombra de dúvida, esta expressão visionária de Erik Jayme, "diálogo das fontes", foi recebida pelo direito brasileiro. Presente, seja na doutrina, seja na prática de nossas lides judiciais, encontra-se assimilada pela jurisprudência, dos Juizados Especiais Cíveis até as mais altas Cortes, desde a primeira decisão da ADIn 2.591, a qual considerou constitucional a aplicação plena do Código de Defesa do Consumidor aos bancos e outros serviços financeiros, de crédito e securitários. (MARQUES, 2012. p. 22)

Como os critérios da escolástica eram três - hierarquia, especialidade e anterioridade -, esta nova visão deve ter "diálogos", baseados em coerência, subsidiariedade e adaptação: a nova hierarquia, que é a coerência dada pelos valores constitucionais e a prevalência dos direitos humanos; a nova especialidade, que é a ideia de complementação ou aplicação subsidiária das normas especiais, entre elas, com tempo e ordem nesta aplicação, primeiro a mais valorativa, depois, no que couberem, as outras; e a nova anterioridade, que não vem do tempo de promulgação da lei, mas sim da necessidade de adaptar o sistema cada vez que uma nova lei nele é inserida pelo legislador. Influências recíprocas guiadas pelos valores constitucionais vão guiar este diálogo de adaptação sistemática (MARQUES, 2012, p. 30-31).

Os "diálogos" acima identificados, superando o conceito de não contradição enraizado nos métodos tradicionais de solução de antinomias, buscará alcançar a complementaridade, a qual permite a aplicação simultânea de normas aparentemente conflitantes, sempre observando os princípios de direito e as determinações constitucionais. Este método privilegia a tratativa sistêmica do ordenamento jurídico, como um todo unitário, favorecendo, assim, a sua coerência. Esta técnica é especialmente importante em face do "pluralismo pós-moderno" de fontes legislativas, conforme defende Cláudia Lima Marques:

\footnotetext{
Em seu Curso Geral de Haia de 1995, Erik Jayme ensinava que diante do "pluralismo pós-moderno" de fontes legislativas, a necessidade de coordenação entre leis no mesmo ordenamento jurídico é exigência de um sistema eficiente e justo. A expressão usada antigamente era a de conflitos de leis no tempo, ou direito intertemporal, a significar que, como haveria "colisão" entre os campos de aplicação dessas leis, por exemplo, uma lei anterior de 1990, como o Código de Defesa do
} 
Consumidor, ou de 2002, como o novo Código Civil brasileiro e uma lei posterior, como a lei sobre consorcio, a solução do "conflito" seria a prevalência de uma e a consequente exclusão (ab-rogação, derrogação, revogação) da outra ou outras do sistema. Nesta visão "perfeita" e "moderna" teríamos a "tese" (lei antiga), a "antítese" (lei nova) e a síntese (revogação), a trazer clareza e certeza ao sistema. Os critérios para resolver os conflitos de leis no tempo seriam três: anterioridade, especialidade e hierarquia, a priorizar-se a hierarquia. Erik Jayme alerta, porém, que os tempos pós-modernos não mais permitem este tipo de clareza e "monossolução", sequer a hierarquia destas leis é clara, mas apenas dos valores constitucionais. Nestes novos tempos, a superação de paradigmas é substituída pela convivência dos paradigmas, a revogação expressa pela incerteza da revogação tácita e por fim pela convivência de leis com campos de aplicação diferentes, mas convergentes, em um mesmo sistema jurídico, plural, fluido, mutável e complexo. O grande mestre de Heidelberg propõe então uma segunda solução, a coordenação dessas fontes: da retirada do sistema (revogação) ou "monólogo" de uma norma só à convivência das normas, ao "diálogo das fontes”. (MARQUES, 2012, p. 27-28)

O método do diálogo das fontes pode, nesse sentido, ser utilizado nas mais diversas áreas do direito, que convirjam entre si. No caso da efetivação da partilha (litigiosa) de quotas de sociedade limitada, decorrente de término de relação conjugal submetida a regime de bens que permita a comunhão de bens, existem, como já visto, dois dispositivos legais que tratam da matéria, sendo um previsto no Código Civil (art. 1.027) - e o outro no Código de Processo Civil (art. 600, parágrafo único). Tendo em vista o aparente conflito existente entre os citados dispositivos de lei, mostra-se oportuna a realização de uma análise dos direitos do ex-cônjuge ou ex-companheiro de sócio, sob a luz do diálogo das fontes.

\section{DIÁlOGO DAS FONTES NA EFETIVAÇÃO DA PARTILHA DAS QUOTAS DA SOCIEDADE LIMITADA}

4.1 Coerência normativa entre as disposições de lei material e processual na partilha de quotas da sociedade limitada

Conforme já demonstrado, existe uma pluralidade de fontes (CPC/15, art. 600, parágrafo único- e CC/02, art. 1.027) que tratam das medidas que podem ser tomadas pelo excônjuge ou ex-companheiro de sócio para efetivar o seu direito à meação, notadamente nos casos em que haja litígio quanto à divisão dos bens. Em comentários ao citado dispositivo do CPC/15, Nelson Nery Junior e Rosa Maria de Andrade Nery firmaram a seguinte opinião:

10. Legitimidade do ex-cônjuge e do ex-companheiro (2). O reconhecimento da legitimidade do cônjuge para a apuração dos haveres foi feito por acórdão do STJ proferido no REsp 114708/MG, o qual modificou posicionamento anterior, segundo o qual o cônjuge poderia apenas partilhar as cotas, mas não o de apurar haveres (Priscila Corrêa da Fonseca. Dissolução parcial, p. 108). A autora menciona também o fato de o CC 1027 - segundo o qual os herdeiros do cônjuge de sócio, ou 
o cônjuge do qual se separou judicialmente, não podem exigir o que lhes cabe como quota social, mas concorrer à divisão periódica de lucros, até que se liquide a sociedade - estar visivelmente em desacordo com esse entendimento. E, com a entrada em vigor do CPC, acrescentamos que o mesmo artigo está derrogado por este CPC 600 par. ún., pois o CPC não só é lei posterior ao CC, como também é norma que trata especificamente de processo e, portanto, hermeneuticamente mais autorizada a dispor sobre a questão de legitimidade. (grifo nosso) (NERY JUNIOR; NERY, 2016. p. 1529)

Foram dois os critérios adotados pelos doutrinadores acima citados, para solucionar a aparente incompatibilidade entre o art. 600, parágrafo único, do $\mathrm{CPC} / 15$ - e o art. 1.027 do $\mathrm{CC} /$ 02: (i) critério da anterioridade, com prevalência do código processual, em decorrência da entrada em vigor posterior; e (ii) critério da especialidade, com prevalência do código processual, por ser hermeneuticamente mais autorizado a dispor sobre questões relacionadas à legitimidade.

Os autores optaram, portanto, pelos tradicionais métodos de solução de antinomias para dar interpretação aos mencionados dispositivos, tendo, por conseguinte, concluído pela derrogação do art. 1.027 do CC/02, em face do advento do art. 600, parágrafo único, do CPC/ 15. Não obstante este estudo concluir pela possibilidade de o ex-cônjuge apurar os haveres da sociedade, buscar-se-á, sob o viés constitucional, demonstrar coerência e complementaridade entre os dispositivos em apreço, no intuito de sugerir uma compreensão mais aprofundada acerca do tema.

Antes de se adentrar na análise dos princípios e direitos constitucionais que orbitam ao redor do tema, cumpre esclarecer o que segue. A legitimação ao ex-cônjuge ou excompanheiro de sócio para apurar haveres da sociedade limitada vem disciplinada dentro de capítulo intitulado "Da ação de dissolução parcial de sociedade". Não obstante, os institutos da apuração de haveres sociais e da dissolução parcial de sociedade são distintos entre si, e, portanto, não devem ser confundidos.

O termo dissolução parcial, desde a sua origem, é utilizado para se referir às hipóteses de desligamento de sócios da sociedade, situações estas que são atualmente classificadas pelo CC/02 (art. 1.028 e seguintes) como resolução da sociedade em relação ao sócio, englobando situações como morte, exclusão e retirada de membros. A respeito do tema, esclarecedoras as lições de Priscila M. P. Corrêa da Fonseca, para quem o termo adotado pelo CC/02 é inadequado:

Efetivamente, como foi esclarecido no Capítulo 1 deste livro, o desligamento do sócio acarreta apenas a extinção parcial da sociedade, à medida que, como contrato plurilateral que é, permite, em razão de sua natureza elástica, a adesão de um número indeterminado de partes. Não há, por via de efeito, em função do afastamento de um dos sócios, o aniquilamento completo da avença societária, mas 
o rompimento limitado desta, relativamente ao sócio que se desvincula. Pode-se, pois, afirmar - e sem receio de errar - que se verifica, no caso, mera dissolução parcial do contrato de sociedade. [...]

Aliás, a expressão dissolução parcial do contrato de sociedade é muito mais adequada do que, por exemplo, resolução parcial do contrato de sociedade - tal como impropriamente denomina o novo Código Civil (art. 1.028 ss) [...] (FONSECA, 2002, p. 68)

A apuração de haveres, por seu turno, surgiu como o meio hábil a averiguar o valor da participação societária detida pelo sócio que se desliga da sociedade, para pagamento em contrapartida das quotas sociais liquidadas ou transmitidas a outrem. A utilização convencional deste instrumento desencadeia, nesse sentido, uma série de obrigações entre a sociedade e o sócio que se desliga. A respeito do tema, elucidativas as lições de Hernani Estrella:

A determinação concreta da quota (ou apuração de haveres, como diz a lei) se resolve num facere, por força do qual a sociedade (sujeito passivo) tem de fazer quanto caiba, pelo contrato ou pela lei, a favor do sócio afastado (sujeito ativo), para que se chegue a determinar o exato montante dos seus haveres. A liquidação, ou mais designadamente o pagamento, vem a ser a prestação posterior, que se traduz num dare, cuja exigibilidade não só se subordina ao que houver sido convencionado, senão ainda tem caráter potencial, já que bem pode suceder inexista crédito algum a favor do ex-sócio. Assim, o procedimento, que se exprime sob a noção genérica de global de "apuração de haveres", envolve prestações de conteúdos bem diferenciados, cada qual tendo o seu momento próprio de realização, mas estando todas filiadas à mesma causa originária. Daqui porque se reconduzem, afinal, ao núcleo maior de relações tipicamente obrigacionais, emergentes do contrato de sociedade. (grifo do autor) (ESTRELLA, 2004, p. 101)

Nessa esteira, o STJ, no julgamento do REsp n. 1139593/SC, de relatoria da Min. Nancy Andrighi, já reconheceu que a ação de apuração de haveres decorrente de dissolução parcial de sociedade tem natureza eminentemente condenatória:

DIREITO PROCESSUAL CIVIL. RECURSO ESPECIAL. AÇÃO DE APURAÇÃO
DE HAVERES. [...] 1. Ação de apuração de haveres ajuizada em 21/7/2005. [...] 6. A
apuração de haveres decorrente de dissolução parcial não é regulada especificamente
por lei, porquanto a própria dissolução parcial representa criação doutrinária e
jurisprudencial, aos poucos incorporada no direito posto. 7. Diante da inexistência
de regras objetivas, aplica-se o procedimento ordinário à ação de apuração de
haveres - ação de natureza eminentemente condenatória. [...] (grifo nosso)
(BRASIL, 2014)

Ao ex-cônjuge de sócio, entretanto, não é atribuído o status de membro da sociedade, motivo pelo qual mostra-se inviável o pleito de dissolução parcial ou resolução da sociedade em seu favor. O paradoxo enfrentado é bem explicado por Hernani Estrella:

As considerações feitas páginas atrás estão a revelar que, em se verificando o afastamento de sócio com a sobrevivência da sociedade, se faz mister determinar e liquidar os seus haveres ou, eventualmente fixar sua responsabilidade ${ }^{7}$. É essa a destinação específica, para a qual a providência foi concedida e aperfeiçoada. Por

7 Segundo o autor, a liquidação da quota pode tanto positivar a inexistência de crédito a favor do sócio, quanto definir débito seu para com a sociedade, a depender do caso. 
conseguinte, o âmbito próprio de sua aplicação é o desligamento de sócio, por qualquer uma das já apontadas causas: morte, despedida voluntária, exclusão, incapacidade superveniente e falência. Isso não obstante, a medida tem sido estendida a casos outros, de todo em todo diferentes. De fato, incomum não é que, por força de convenção ou assentimento posterior, os interessados se sirvam dessa via para arrolarem bens de cônjuge sócio, na eventualidade de extinção da comunidade conjugal (morte de um dos cônjuges ou desquite). São casos estes em que a medida, de que ora nos ocupamos, é aplicada fora do regime societário mercantil, para o qual foi criada e sucessivamente aperfeiçoada e onde, também, encontramos justificação plena. Transplantada, de tal jeito, para a esfera do direito civil, suscita problemas aqui de solução assaz difícil. É que em nenhum destes casos (morte da mulher de sócio, desquite ou anulação de casamento) há ruptura do vínculo social, pelo que toca ao sócio cônjuge, de maneira que vem a faltar o pressuposto lógico-jurídico que explica e informa a instituição. (grifo nosso) (ESTRELLA, 2004, p. 131-132)

Os efeitos da ação ajuizada pelo meeiro com fito exclusivo de apuração de haveres, portanto, hão de ser diferentes daqueles decorrentes de ação ajuizada por sócio que se desliga da sociedade. Isto, pois, no primeiro caso faltaria o pressuposto lógico-jurídico para que o excônjuge de sócio pleiteasse a efetiva dissolução parcial da sociedade, com a respectiva liquidação da quota social sobre a qual tivesse direito.

Feitas estas considerações, buscar-se-á, adiante, realizar uma breve ponderação acerca da coerência entre os dispositivos constitucionais e princípios que permeiam os direitos do meeiro na partilha de bens do casal. O direito de propriedade foi expressamente inserido no rol de direitos fundamentais pela $\mathrm{CR} / 88$ (art. $5^{\circ}$, caput), garantido pelo inciso XXII do citado dispositivo. Os direitos fundamentais, entretanto, não são absolutos, conforme leciona Kildare Gonçalves Carvalho:

Não existe direito absoluto. Assim, os direitos fundamentais não são absolutos nem ilimitados. Encontram limitações na necessidade de se assegurar aos outros o exercício desses direitos, como têm ainda limites externos, decorrentes da necessidade de sua conciliação com as exigências da vida em sociedade, traduzidas na ordem pública, ética social, autoridade do Estado, etc..., resultando, daí, restrições dos direitos fundamentais em função dos valores aceitos pela sociedade. (CARVALHO, 1999, p. 198)

$\mathrm{O}$ direito fundamental à propriedade do ex-cônjuge ou ex-companheiro de sócio, portanto, não é absoluto. No caso, a prerrogativa encontra limites na sua função social, insculpida no art. $5^{\circ}$, inciso XXIII, da CR/88, conforme leciona Kildare Gonçalves Carvalho:

Ao dispor que 'a propriedade atenderá a sua função social”, o art. 5, XXIII, da Constituição a desvincula da concepção individualista do século XVIII. A propriedade, sem deixar de ser privada, se socializou, com isso significando que deve oferecer à coletividade uma maior utilidade, dentro da concepção de que o social orienta o individual.

A função social da propriedade, que corresponde a uma concepção ativa e comissiva do uso da propriedade, faz com que o titular do direito seja obrigado a fazer, a valerse de seus poderes e faculdades, no sentido do bem comum. (CARVALHO, 1999, p. 215) 
Significa dizer que o direito de propriedade não pode ser exercido de forma a prejudicar os direitos de terceiros ${ }^{8}$. A função social da propriedade, ainda, constitui princípio da ordem econômica, conforme estabelece o art. 170, inciso II da CR/88. A partir deste fundamento, desenvolveu-se o princípio da função social da empresa, o qual preceitua que as sociedades empresárias não têm a finalidade única de geração de lucros, mas uma obrigação perante a sociedade como um todo, notadamente empregados, fornecedores, investidores, clientes e terceiros interessados. Passou-se a reconhecer, portanto, que as sociedades empresárias cumprem um importante papel na sociedade, pela geração de empregos e manutenção da atividade econômica, surgindo, nesta toada, o princípio da preservação da empresa9 .

Nesse sentido, o exercício do direito de propriedade pelo meeiro que resulte na responsabilização da sociedade ao pagamento dos haveres apurados, mediante liquidação de quotas partilhadas, poderia resultar em graves danos sociais, tais como a dispensa de empregados, a falta de pagamento a fornecedores, o prejuízo de investidores e clientes ${ }_{\overline{-}}^{-}$e no descumprimento de obrigações em geral perante terceiros. Ou seja, do ponto de vista da coerência entre princípios, a liquidação imediata das quotas da sociedade limitada a pedido do ex-cônjuge ou ex-companheiro de sócio parece ir de encontro com a função social da sociedade.

Ainda, há de ser considerada a autonomia da pessoa jurídica, que tem personalidade própria e, portanto, não se confunde com seus sócios. Esta autonomia, típica das pessoas jurídicas, encontra respaldo no princípio societas distat a singulis, segundo Osmar Brina Corrêa-Lima:

18. Societas distat a singulis. Não se confundem as pessoas dos sócios e a da sociedade. Não se confundem nem as personalidades, nem os nomes, e nem os patrimônios da sociedade e de cada um de seus sócios. Esse princípio clássico traduziu-se no caput do art. 20 do Código Civil brasileiro de 1916: "As pessoas jurídicas têm existência distinta da dos seus membros". Embora o Código Civil brasileiro de 2002 não reproduza a literalmente esse dispositivo, o principio nele consagrado continua atual e válido. (grifo do autor) (CORRÊA-LIMA, 2006, p. 21)

Considerando que a permissão ao meeiro de pleitear de imediato a dissolução parcial da sociedade limitada importaria, em regra, responsabilização da pessoa jurídica pela liquidação das quotas detidas em copropriedade, pode-se dizer que, no caso, haveria uma violação ao princípio da autonomia da pessoa jurídica.

A partir das constatações realizadas acima, aparenta ser inviável a responsabilização imediata da sociedade limitada ao pagamento dos haveres apurados pelo ex-cônjuge ou ex8 Uma vertente deste princípio é o art. 187 do CC/02, que veda o abuso de direito de forma geral. 9 O princípio da preservação da empresa, demarcado de forma implícita no art. 170 da CR/88, foi expressamente consagrado no ordenamento pátrio pelo art. 47 da Lei 11.101/05. 
companheiro de sócio, eis que: (i) faltaria o pressuposto lógico-jurídico (status de sócio) para que o meeiro pleiteasse a efetiva dissolução parcial da sociedade; (ii) o direito de propriedade deve respeitar os limites de sua função social, observada, ainda, a função social da empresa; e (iii) as responsabilidades do sócio (restituir ao meeiro a parte que lhe cabe no patrimônio do casal), em regra, não podem ser atribuídas à sociedade. No caso, este entendimento corrobora a validade da disposição do art. 1.027 do $\mathrm{CC} / 02$, que determina que o meeiro não poderá, desde logo, exigir a parte que lhe cabe na quota social.

Entretanto, há de ser analisado também o direito constitucional à livre associação, previsto no art. $5^{\circ}$, inciso $\mathrm{XX}$ da $\mathrm{CR} / 88$, o qual determina que "ninguém poderá ser compelido a associar-se ou a permanecer associado". No caso, este princípio se mostra pertinente à análise da matéria, na medida em que o meeiro, em muitos casos, se vê obrigado a permanecer como coproprietário de quotas sociais, mesmo contra sua vontade. Segundo Marlon Tomazette, essa liberdade de associação abrange tanto as associações em sentido estrito, quanto às sociedades, podendo abranger qualquer modalidade de associação de pessoas (TOMAZETTE, 2011, p. 209-228). O citado doutrinador leciona, ainda, que o princípio em comento representa uma limitação à autonomia privada:

[...] há que se reconhecer também a liberdade de associação como limitadora da autonomia privada, na medida em que representa um direito fundamental de liberdade aplicado as relações entre particulares. Neste momento, a tutela da autonomia privada não é suficiente para proteger a dignidade da pessoa humana em sociedades desiguais como a nossa (Morais, 2008, p. 39). Dentro dessa perspectiva, a liberdade de associação constitucionalmente assegurada pelo art. $5^{\circ}, \mathrm{XX}$, da $\mathrm{CF} / 1988$ deverá ser usada como fonte de solução das controvérsias atinentes as relações privadas societárias. (TOMAZETTE, 2011, p. 209-228)

Verifica-se, sob este prisma, que, com base no princípio da livre associação, o meeiro poderia pleitear a extinção da sua copropriedade sobre quotas da sociedade limitada. Todavia, o direito do ex-cônjuge parece, novamente, encontrar limites na função social da empresa, na medida em que o exercício do seu direito poderia afetar o regular desenvolvimento das atividades sociais. Diante desta constatação, buscar-se-á, no tópico seguinte, sugerir a forma pela qual o ex-cônjuge ou ex-companheiro de sócio poderá efetivar a partilha de quotas da sociedade limitada, inclusive pela liquidação destas, a depender da análise do caso concreto.

\subsection{Da efetivação da partilha de quotas da sociedade limitada}

A legitimação a apurar haveres possibilitou ao meeiro a fixação, em moeda corrente, do valor das quotas sobre as quais recairiam os seus direitos. Isto, pois, conforme já decidiu o 
STJ, no julgamento do REsp n. 1.459.192-CE, de relatoria originária do Min. Ricardo Villas

Bôas Cueva, o juízo da partilha não é competente para apreciar as questões que demandem extensa dilação probatória (Informativo de Jurisprudência n. 0566), como é o caso da apuração de haveres ${ }^{10}$ :

DIREITO PROCESSUAL CIVIL. COMPETÊNCIA PARA JULGAR DISSOLUÇÃO PARCIAL DE SOCIEDADE LIMITADA COM APURAÇÃO DE HAVERES. Compete ao juízo civel - e não ao juízo de sucessões no qual tramita o inventário - julgar, com consequente apuração de haveres do de cujus, dissolução parcial de sociedade limitada que demande extensa dilação probatória. De fato, conforme entendimento do STJ, "Cabe ao juízo do inventário decidir, nos termos do art. 984 do CPC, 'todas as questões de direito e também as questões de fato, quando este se achar provado por documento, só remetendo para os meios ordinários as que demandarem alta indagação ou dependerem de outras provas', entendidas como de 'alta indagação' aquelas questões que não puderem ser provadas nos autos do inventário" (REsp 450.951-DF, Quarta Turma, DJe 12/4/2010). Nesse diapasão, questões de alta indagação, que, por exigirem extensa dilação probatória, extrapolam a cognição do juízo do inventário, devem ser remetidas aos meios ordinários. Logo, é no juízo cível que haverá lugar para a dissolução parcial das sociedades limitadas e consequente apuração de haveres do de cujus, visto que, nessa via ordinária, deve ser esmiuçado, caso a caso, o alcance dos direitos e obrigações das partes interessadas - os quotistas e as próprias sociedades limitadas -, indiferentes ao desate do processo de inventário. Deixa-se, pois, ao juízo do inventário a atribuição jurisdicional de descrever o saldo advindo com a liquidação das sociedades comerciais, para que possa dar à herança a devida partilha, não comportando seu limitado procedimento questões mais complexas que não aquelas voltadas para o levantamento, descrição e liquidação do espólio. (grifo nosso) (BRASIL, 2015)

Consequentemente, a sentença de partilha se restringe a determinar o percentual das quotas sobre o qual os direitos recairiam, cabendo ao juízo cível, a partir da autorização do art. 600, parágrafo único, do CPC/15, processar e julgar a ação de apuração de haveres da sociedade limitada. No caso, a sentença proferida nas vias ordinárias, que fixará em moeda corrente a expressão econômica das quotas submetidas à meação, dotaria de liquidez a decisão proferida pelo juízo de família na ação de partilha.

Parte da doutrina considera que a sentença que julga a partilha $(\mathrm{CPC} / 15$, art. 654) tem natureza constitutiva, por resultar na extinção da comunhão uma vez existente entre os envolvidos, definindo os exatos quinhões cabíveis a cada parte sobre os bens partilhados, conforme leciona José Miguel Garcia Medina (2017), a partir das lições de Antonio Carlos Marcato (2015). Há doutrinadores, entretanto, que entendem ser meramente declaratória a

10 Nos casos de litígio, o procedimento para realização da partilha é aquele previsto para as hipóteses de inventário em decorrência de morte, tanto no CPC/73 (art. 1.121, § $1^{\circ}$, e art. 982 e seguintes), quanto no CPC/15 (art. 731, parágrafo único, e art. 647 a 658). A respeito da necessidade de remessa dos autos às vias ordinárias em caso de questão de alta indagação, esclarecedoras as lições de Yussef Said Cahali: "A partilha dos bens da sociedade conjugal desfeita segue, em linhas gerais, o mesmo ritual da partilha sucessória, inclusive quanto à remoção de inventariante e remessa das partes às vias ordinárias, quando se trata de questões de alta indagação" (CAHALI, Yussef Said. Separações conjugais e divórcio. 12a ed. São Paulo: Editor Revista dos Tribunais, 2011, p. 727) 
sentença que julga a partilha, conforme se infere das lições de Sérgio Shimura (1997). É cediço, todavia, que a sentença que julga a partilha não poderia ter natureza condenatória.

Tradicionalmente, predominava o entendimento de que apenas as sentenças condenatórias seriam passíveis de execução. Há na atualidade, entretanto, vivo debate tanto na doutrina quanto na jurisprudência, acerca da possibilidade de utilização deste remédio processual com base em sentenças constitutivas ou declaratórias (SHIMURA, 1997, p. 252253). Nelson Nery Junior e Rosa Maria de Andrade Nery, posicionando-se em consonância com a doutrina tradicional, defendem que as sentenças de natureza condenatória ou constitutiva são inexequíveis:

6. Sentença civil declaratória. Inexequibilidade. [...] Como na sentença meramente declaratória (CPC 19) não há imposição de obrigação nem de sanção, traço caracterizador da eficácia executiva da sentença, não contém ela aptidão para impor a prática de atos de execução, não contém força executiva. [...]

8. Sentença civil constitutiva. Inexequibilidade. As sentenças constitutivas não são passíveis de execução e, portanto, não estão sujeitas às regras do cumprimento de sentença estabelecidas pelo CPC et. seq. O que se constituiu ou desconstituiu já o foi pelo comando da sentença, independentemente de outra providência executória. (grifo do autor) (NERY JUNIOR; NERY, 2016, p. 1368-1369)

Grande parte da doutrina, entretanto, vem entendendo pela possibilidade de se ingressar com ação de execução fundada em sentença de natureza declaratória e constitutiva. Isso, pois, a necessidade de se submeter matéria já decidida a novo processo de conhecimento representaria verdadeiro comprometimento da coisa julgada, além de importar em atividade meramente burocrática e desnecessária, conforme leciona Teori Albino Zavascki:

Se a norma jurídica individualizada está definida, de modo completo, por sentença,
não há razão alguma, lógica ou jurídica, para submetê-la, antes da execução, a um
segundo juízo de certificação, até porque a nova sentença não poderia chegar a
resultado diferente do da anterior, sob pena de comprometimento da garantia da
coisa julgada, assegurada constitucionalmente. Instaurar a cognição sem oferecer às
partes e principalmente ao juiz outra alternativa de resultado que não um já
prefixado representaria atividade meramente burocrática e desnecessária, que
poderia receber qualquer outro qualificativo, menos o de jurisdicional.
(ZAVASCKI, 2003, p. 52)

O STJ, seguindo esta linha de entendimento, no julgamento dos Embargos de Divergência no REsp n. 606.266/RS, de relatoria do citado Min. Teori Albino Zavascki, decidiu que a sentença declaratória pode ser dotada de eficácia executiva:

PROCESSUAL CIVIL. [...] EFICÁCIA EXECUTIVA DA SENTENÇA DECLARATÓRIA [...]. 1. No atual estágio do sistema do processo civil brasileiro não há como insistir no dogma de que as sentenças declaratórias jamais têm eficácia executiva. $\mathrm{O}$ art. $4^{\circ}$, parágrafo único, do CPC considera "admissível a ação declaratória ainda que tenha ocorrido a violação do direito", modificando, assim, o padrão clássico da tutela puramente declaratória, que a tinha como tipicamente preventiva. Atualmente, portanto, o Código dá ensejo a que a sentença declaratória possa fazer juízo completo a respeito da existência e do modo de ser da relação 
jurídica concreta. 2. Tem eficácia executiva a sentença declaratória que traz definição integral da norma jurídica individualizada. Não há razão alguma, lógica ou jurídica, para submetê-la, antes da execução, a um segundo juízo de certificação, até porque a nova sentença não poderia chegar a resultado diferente do da anterior, sob pena de comprometimento da garantia da coisa julgada, assegurada constitucionalmente. E instaurar um processo de cognição sem oferecer às partes e ao juiz outra alternativa de resultado que não um, já prefixado, representaria atividade meramente burocrática e desnecessária, que poderia receber qualquer outro qualificativo, menos o de jurisdicional. (BRASIL, 2006)

A exequibilidade das sentenças declaratória e constitutiva é também defendida por Humberto Theodoro Junior, que defende que o $\mathrm{CPC} / 15$, no art. 515, inciso I, passou a reconhecer expressamente a medida:

[...] o novo Código manteve-se na linha de ampliar a força executiva para além dos tradicionais julgados de condenação, acolhendo corrente doutrinária e jurisprudencial que, no regime do Código anterior, já vinha reconhecendo possibilidade, em certos casos, de instaurar execução também com base em decisões declaratórias e constitutivas. A redação do art. 515, I, do NCPC, apoiando-se no reconhecimento judicial de exigibilidade de obrigação, como elemento capaz de identificar a decisão básica do cumprimento forçado do provimento judicial, evidenciou a possibilidade de incluir-se em tal procedimento, também, os julgados declaratórios e constitutivos, desde que neles se contenham os dados configurados de obrigação exigível, que, para tanto, haverá certamente de ser certa e líquida. (BRASIL, 2006)

Com base no art. 515, inciso I, do CPC/15, e no julgado dos Embargos de Divergência no REsp n. 606.266/RS pelo STJ, Luiz Guilherme Marinoni também defende esta corrente:

[...] é de se concluir que a sentença ou decisão interlocutória que, ainda sem "condenar" o réu ao adimplemento de obrigação, contenha todos os elementos capazes de tornar certa a exigibilidade de certa prestação, é título executivo judicial. (MARINONI; ARENHART; MITIDIERO, 2017, p. 633)

Independentemente da natureza que se atribua à sentença de partilha no divórcio, seja constitutiva ou declaratória, entende-se, diante das posições doutrinárias e jurisprudencial colacionadas acima, que em determinados casos seja possível a sua execução, para recebimento dos bens conferidos a um dos consortes, mas que esteja sob titularidade ou custódia de outro. No caso, parece adequado que o cumprimento da sentença de partilha seja processado e julgado no próprio juízo de família, conforme já decidiu o TJMG, com base no art. 516 do CPC/15, no julgamento do Conflito de Competência 1.0000.17.015386-0/000, de relatoria do Des. Renato Dresch:

CONFLITO NEGATIVO DE COMPETÊNCIA - CUMPRIMENTO DE SENTENÇA - DIVÓRCIO - PARTILHA - COMPETÊNCIA DO JUÍZO DA CAUSA ORIGINÁRIA. 1 - A execução de título executivo judicial (cumprimento de sentença) far-se-á nos próprios autos e que o juízo competente para processá-la será o mesmo da causa que ensejar o título exequendo; 2 - Se a ação em que foi suscitado o conflito de competência visa apenas o cumprimento da sentença que determinou a partilha dos bens do casal, nos autos da ação de divórcio litigioso, a competência para seu processamento e julgamento é do juízo que proferiu a sentença, a teor do art. 516 do CPC/2015. (MINAS GERAIS, 2017) 
Assim, munido com as sentenças proferidas nos processos de partilha e apuração de haveres, entende-se que o meeiro estaria apto a pleitear, em face do seu ex-consorte, mas não da sociedade ou dos demais sócios, o pagamento da expressão econômica apurada, mediante cumprimento de sentença. No caso, todos os bens do sócio responderiam pelo pagamento ao meeiro do valor das quotas sobre as quais recaíssem os direitos deste, nos termos do art. 789 do $\mathrm{CPC} / 15$.

No âmbito do cumprimento de sentença, as quotas da sociedade limitada poderiam, nesse sentido, responder pela obrigação do sócio em face do seu ex-consorte, possibilitando, consequentemente, a penhora da quota social, desde que verificada previamente a possibilidade de constrição de outros bens do devedor. Esta interpretação, que garante o acesso à justiça sem deixar de respeitar a função social da empresa, está de acordo com o entendimento fixado pelo STJ no julgamento do REsp 1284988/RS, de relatoria do Min. Luis Felipe Salomão (Informativo de Jurisprudência 0559):

DIREITO CIVIL E PROCESSUAL CIVIL. PENHORA DE QUOTAS SOCIAIS NA PARTE RELATIVA À MEAÇÃO. A existência de divida alimentar não autoriza a penhora imediata de cotas sociais pertencentes à atual companheira do devedor na parte relativa à meação, sem que antes tenha sido verificada a viabilidade de constrição do lucro relativo às referidas cotas e das demais hipóteses que devam anteceder a penhora (art. 1.026, c/c art. 1.053, ambos do CC). [...] Igualmente, não se pode olvidar que a jurisprudência STJ, nos moldes do disposto no art. 655 , VI, do CPC, também admite a penhora de quotas sociais do executado para satisfação de crédito exequendo, ainda que exista vedação no contrato social da sociedade empresária à livre alienação das cotas, sem que isso, todavia, implique a admissão como sócio daquele que arrematar ou adjudicar (REsp 327.687-SP, Quarta Turma, DJ 15/4/2002). Contudo, não se pode ignorar que o advento do art. 1.026 do $\mathrm{CC}$, ao dispor que "O credor particular de sócio pode, na insuficiência de outros bens do devedor, fazer recair a execução sobre o que a este couber nos lucros da sociedade, ou na parte que lhe tocar em liquidação", relativizou a penhorabilidade das quotas sociais, que só deve ser efetuada acaso superadas as demais possibilidades conferidas pelo dispositivo mencionado, consagrando o princípio da conservação da empresa ao restringir a adoção de solução que possa provocar a dissolução da sociedade empresária e maior onerosidade da execução, visto que a liquidação parcial da sociedade empresária, por débito estranho à sociedade, implica a sua descapitalização, afetando os interesses dos demais sócios, empregados, fornecedores e credores da empresa. Nesse mesmo diapasão, propugna a doutrina que não cabe ao credor particular do sócio "escolher se vai receber os lucros ou se vai liquidar parte da sociedade como forma de pagamento do que lhe é devido, seria condenar as sociedades a um futuro incerto e possivelmente desastroso, caso a diminuição de capital afete sua capacidade produtiva. Nessa última situação acabaria, ainda, punindo a sociedade por obrigação que lhe é estranha, da qual não tomou parte, mas que poderia ser adimplida de outro modo", devendo sempre que possível ser feita a opção pela retenção dos lucros, correspondentes à quota social do devedor. Convém consignar que o Enunciado 387 da IV Jornada de Direito Civil propõe que a opção entre fazer a execução recair sobre o que ao sócio couber no lucro da sociedade ou na parte em que lhe tocar em dissolução orienta-se pelos princípios da menor onerosidade e da função social da empresa. Assim, tendo em vista o disposto no art. 1.026, $\mathrm{c} / \mathrm{c}$ o art. 1.053, ambos do CC, e os princípios da conservação da empresa e da menor onerosidade da execução, cabe ao exequente 
requerer a penhora dos lucros relativos às quotas sociais correspondentes à meação do devedor - o que também é a inteligência do art. 1.027 do CC -, não podendo ser deferida, de modo imediato, a penhora de quotas sociais de sociedade empresária em plena atividade, em prejuízo de terceiros, por dívida estranha à referida pessoa jurídica. (BRASIL, 2015)

Com relação à penhora de quotas sociais, cumpre demonstrar, ainda, que o $\mathrm{CPC} / 15$, no $\S 5^{\circ}$ do art. 861 , determinou que se a liquidação da quota social for excessivamente onerosa para a sociedade, o juiz poderá determinar o leilão judicial desta. Ou seja, o novo diploma processual cuidou de resguardar a preservação e função social da empresa.

A interpretação sugerida parece, diante do exposto, harmonizar o direito constitucional de propriedade e os princípios de liberdade de associação e acesso à justiça, com os princípios da preservação e função social da empresa. Isto, pois, além de atender aos anseios do cônjuge meeiro, a medida preza pela manutenção da sociedade, ao impossibilitar a liquidação direta das quotas sociais a partir da dissolução parcial de sociedade.

\section{CONCLUSÃO}

$\mathrm{O}$ art. 1.027 do $\mathrm{CC} / 02$; e art. 600, parágrafo único, do $\mathrm{CPC} / 15$, são fontes normativas distintas que tratam do direito do ex-cônjuge ou ex-companheiro de sócio, com relação ao direito de partilha de quotas sociais submetidas à meação. O presente estudo buscou, nesse sentido, traçar noções gerais acerca dos tradicionais métodos para soluções de antinomias e, ainda, acerca da teoria do diálogo das fontes, para, após optar pela prevalência deste em face daquele, sugerir uma interpretação coerente e finalística a ser dada aos dispositivos aparentemente confrontantes.

Concluiu-se, em um primeiro momento, que o meeiro não teria o direito de exercer irrestritamente os seus direitos constitucionais de propriedade e livre associação, tendo em vista que estes encontram limites nos princípios da função social e preservação da empresa. Não obstante, sugeriu-se entendimento de que, munido com as sentenças proferidas nos processos de partilha e apuração de haveres, o meeiro estaria apto a ajuizar cumprimento de sentença em face do seu ex-consorte, sócio da sociedade limitada. No caso, o devedor responderia com todos os seus bens, inclusive as próprias quotas sociais, desde que, na esteira do entendimento consolidado pelo STJ, fosse verificada previamente a possibilidade de constrição de outros bens do executado.

Com base na interpretação sugerida, pode-se concluir que a limitação imposta ao meeiro pelo art. 1.027 do CC/02, no sentido de este não poder exigir desde já a parte que lhe cabe na 
quota social, permanece em pleno vigor, eis que a legitimação para se apurar os haveres da sociedade limitada não poderia importar, de imediato, na condenação da sociedade para liquidar a participação societária respectiva.

Além disto, é importante notar que o direito do meeiro de receber os lucros da sociedade, até que esta se liquide, também permanece intacto, eis que a disposição processual recém introduzida no ordenamento pátrio determina que o ex-cônjuge ou ex-companheiro de sócio poderá requerer a apuração de seus haveres na sociedade, não sendo este, portanto, o único caminho processual a ser seguido para satisfação do direito à meação. $\mathrm{O}$ meeiro poderia optar, nesse sentido, por receber os lucros da sociedade, até que fosse determinada a liquidação desta.

Ademais, a percepção de lucros da sociedade é, na prática forense, um válido instrumento acautelatório, apto a ser utilizado para assegurar ao meeiro o recebimento dos frutos decorrentes das quotas sociais, ao longo do trâmite processual.

Conclui-se, diante das constatações acima, alcançadas a partir do diálogo das fontes, que o art. 600, parágrafo único, do $\mathrm{CPC} / 15$, não derrogou o art. 1.027 do $\mathrm{CC} / 02$, que continua com suas disposições em pleno vigor. Sugere-se, nesse sentido, a possibilidade de coexistência harmônica entre os citados dispositivos, sem que um interfira na validade do outro.

\section{REFERÊNCIAS}

ATALIBA, Geraldo. Prefácio ao livro de Lourival Vilanova, As estruturas lógicas e o sistema do direito positivo, São Paulo: Editora Max Limonad, 1997.

BOBBIO, Norberto. Teoria do ordenamento jurídico. Trad. Maria Celeste Cordeiro Leite dos Santos. Brasília: UnB, 1994.

BRASIL. Constituição da República Federativa do Brasil de 1988. Disponível em:

$<$ http://www.planalto.gov.br/ccivil_03/constituicao/constituicaocompilado.htm>. Acesso em: 07 fev. 2017.

. Lei 10.406, de 10 de janeiro de 2002. Código Civil. Disponível em:

<http://www.planalto.gov.br/ccivil_03/leis/2002/L10406.htm>. Acesso em: 07 fev. 2017.

. Lei 13.105, de 16 de março de 2015. Código de Processo Civil. Disponível em:

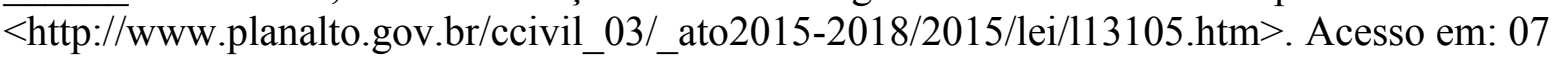
fev. 2017. 
Superior Tribunal de Justiça. REsp n. 1139593/SC, Rel. Ministra Nancy Andrighi, Terceira Turma, julgado em 22 abr. de 2014, DJe 02 mai. de 2014. Disponível em:

$<$ http://www.stj.jus.br/SCON/jurisprudencia/toc.jsp? processo $=1139593 \& \& b=$ ACOR\&thesaurus $=$ JURIDICO\&p=true $>$ Acesso em: 15 jul. 2017.

. Superior Tribunal de Justiça. REsp n. 114.708/MG, Rel. Min. Waldemar Zveiter, Rel. p/ Acórdão Min. Carlos Alberto Menezes Direito, Terceira Turma, julgado em 19/02/2001, DJ 16/04/2001, p. 105. Disponível em:

$<\mathrm{http}: / / \mathrm{www}$. stj.jus.br/SCON/jurisprudencia/toc.jsp? processo $=114708 \& \& b=$ ACOR $\&$ thesaurus $=$ JURIDICO\&p=true $>$. Acesso em: 15 jun. 2017

. Superior Tribunal de Justiça, RE n. 1284988/RS, Informativo de Jurisprudência 0559, Quarta Turma, Rel. Min. Luis Felipe Salomão, julgado em 19 mar. de 2015. Disponível em:

$<$ https://ww2.stj.jus.br/jurisprudencia/externo/informativo/?

acao $=$ pesquisar $\&$ processo $=1284988 \&$ operador $=e \& b=I N F J \&$ thesaurus $=$ JURIDICO $>$. Acesso em: 20 abr. 2017.

. Superior Tribunal de Justiça. REsp n. 609.266/RS, Rel. Ministro Teori Albino Zavascki, Primeira Seção, julgado em 23 ago. 2006, DJ 11 set. de 2006, p. 223, Disponível em:

$<$ http://www.stj.jus.br/SCON/jurisprudencia/toc.jsp? processo $=609266 \& \& b=$ ACOR $\&$ thesaurus $=J U R I D I C O \& p=$ true $>$ Acesso em: 28 jul. 2017.

. Superior Tribunal de Justiça. REsp n. 1.459.192-CE, Rel. originário Ricardo Villas Bôas Cueva, Rel. para acórdão João Otávio de Noronha, julgado em 23 jun. de 2015, DJe 12 ago. de 2015. Disponível em:

$<$ http://www.stj.jus.br/SCON/jurisprudencia/toc.jsp?

processo $=1459192 \& \& b=$ ACOR $\&$ thesaurus $=$ JURIDICO $\& p=$ true $>$ Acesso em: 10 abr. 2017.

CAHALI, Yussef Said. Separações conjugais e divórcio. 12a ed. São Paulo: Editor Revista dos Tribunais, 2011.

CARVALHO, Kildare Gonçalves. Direito constitucional didático. $6^{\mathrm{a}}$ ed. Belo Horizonte: Del Rey, 1999.

CORRÊA-LIMA, Osmar Brina. Sociedade limitada. Rio de Janeiro: Forense, 2006.

DINIZ, Maria Helena. Lei de introdução ao Código Civil brasileiro interpretada. 15 ed. São Paulo: Saraiva, 2010.

DREI - Departamento de Registro Empresarial e Integração. Dados extraídos do Relatório Estatístico Mensal Nacional - 2015. Disponível em:

$<$ http://drei.smpe.gov.br/assuntos/estatisticas/2022-relatorio-estatistico-mensal-nacional $>$. Acesso em: 07 fev. 2017

ESTRELLA, Hernani. Apuração dos Haveres de Sócio. $4^{\mathrm{a}}$ ed. Rio de Janeiro: Forense, 2004. 
FERRAZ JR., Tércio Sampaio. Antinomia, in Enciclopédia Saraiva do Direito. São Paulo: Saraiva, 1978.

FONSECA, Priscila M. P. Corrêa da. Dissolução parcial, retirada e exclusão de sócio. São Paulo: Editora Atlas, 2002.

FONSECA, Priscila M. P. Corrêa da; SZTAJN, Rachel. Código Civil Comentado: Direito de Empresa, vol. XI. São Paulo: Editora Atlas, 2008.

IBGE - Instituto Brasileiro de Geografia e Estatística, Estatísticas do Registro Civil 2013, Disponível em:

$<$ http://www.ibge.gov.br/home/estatistica/populacao/registrocivil/2013/default_xls.shtm>. Acesso em: 07 fev. 2017.

LUCENA, José Waldecy. Das Sociedades Limitadas. 6a ed. Rio de Janeiro: Renovar, 2005.

MARCATO, Antonio Carlos. [Anotações aos artigos 335 ao 342]. In: CRUZ E TUTTI; José Rogério; FERREIRA FILHO, Manoel Caetano; APRIGLIANO, Ricardo de Carvalho; DOTTI, Rogéria Fagundes; MARTINS, Sandro Gilbert (Coordenadores). Código de Processo Civil Anotado. AASP. OAB-PR. 2015.

MARINONI, Luiz Guilherme; ARENHART, Sérgio Cruz; MITIDIERO, Daniel. Novo Código de Processo Civil comentado. São Paulo: Editora Revista dos Tribunais, 2017.

MARQUES, Claudia Lima (Coord.). Diálogo das fontes: do conflito à coordenação de normas do direito brasileiro. São Paulo: Editora Revista dos Tribunais, 2012.

MEDINA, José Miguel Garcia. Curso de Direito Processual Civil Moderno. $3^{\text {a }}$ ed. São Paulo: Editora Revista dos Tribunais, 2017.

MINAS GERAIS. Tribunal de Justiça de Minas Gerais. Apelação Cível n 1.0261.07.0558323/005, relator Desembargador Mauro Soares de Freitas, 16 Câmara Cível, DJE 27 de out. de 2006. Disponível em:

$<$ http://www5.tjmg.jus.br/jurisprudencia/

pesquisaNumeroCNJEspelhoAcordao.do;jsessionid=DEF98DC9439084954F54A391719D34 4E.juri_node1?

numeroRegistro $=1 \&$ totalLinhas $=1 \&$ linhasPorPagina $=10 \&$ numeroUnico $=1.0261 .07 .055832$ 3\%2F005\&pesquisaNumeroCNJ=Pesquisr $>$. Acesso em 11 jun. 2017.

. Tribunal de Justiça de Minas Gerais. Conflito de Competência 1.0000.17.0153860/000, Relator (a): Des.(a), 4 CÂMARA CÍVEL, julgamento em 06 jul. de 2017, publicação da súmula em 12 jul. de 2017. Disponível em:

$<$ http://www5.tjmg.jus.br/jurisprudencia/

pesquisaNumeroCNJEspelhoAcordao.do;jsessionid=DEF98DC9439084954F54A391719D34 4E.juri_node1?

numeroRegistro $=1 \&$ totalLinhas $=1 \&$ linhasPorPagina $=10 \&$ numeroUnico $=1.0000 .17 .015386-$ 0\%2F000\&pesquisaNumeroCNJ=Pesquisar>. Acesso em: 27 jul. 2017. 
MIRAGEM, Bruno Nubens Barbosa; BRONZATTI, Ítalo. Direitos, deveres e responsabilidade civil: uma análise da prestação do serviço público de energia elétrica através do diálogo das fontes. Revista da Faculdade de Direito da UFRGS, Porto Alegre, n. 36, p. 207-229, ago. 2017.

NERY JUNIOR, Nelson; NERY, Rosa Maria de Andrade. Código de processo civil comentado. 16 ed. São Paulo: Editora Revista dos Tribunais, 2016.

SÃO PAULO. Tribunal de Justiça do Estado de São Paulo. Apelação Cível no $0123702-$ 08.2008.8.26.0000, relator Desembargador Erickson Gavazza Marques, $5^{\mathrm{a}}$ Câmara de Direito Privado, DJE 01 ago de 2013. Disponível em:

$<$ https://esaj.tjsp.jus.br/cjsg/resultadoCompleta.do>. Acesso em 10. Jun. 2017.

. Tribunal de Justiça de São Paulo. Apelação 0010761-14.2012.8.26.0344;

Relator: Tasso Duarte de Melo; Órgão Julgador: $2^{\mathrm{a}}$ Câmara Reservada de Direito Empresarial; Foro de Marília - 2a . Vara Cível; Data do Julgamento: 17/11/2014; Data de Registro: 11/12/2014. Disponível em:

$<$ https://esaj.tjsp.jus.br/cjsg/resultadoCompleta.do>. Acesso em: 11 jun. 2017.

. Tribunal de Justiça de São Paulo. Apelação 1013769-49.2014.8.26.0008, Relator: Francisco Loureiro, Data de Julgamento: 22/02/2016, $1^{\text {a }}$ Câmara Reservada de Direito Empresarial, Data de Publicação: 22/02/2016. Disponível em:

$<$ https://esaj.tjsp.jus.br/cjsg/resultadoCompleta.do>. Acesso em: 11 jun. 2017.

SHIMURA, Sérgio. Título executivo. São Paulo: Saraiva, 1997, p. 252-253. In: DIDIER, Fredie. Sentença constitutiva e execução forçada. Disponível em:

$<\mathrm{http}: / / \mathrm{www}$.frediedidier.com.br/wp-content/uploads/2012/11/A-senten\%C3\%A7aconstitutiva-pode-ser-t\%C3\%ADtulo-executivo.pdf>. Acesso em: 24 ago. 2017.

THEODORO JÚNIOR, Humberto. Curso de Direito Processual Civil - execução forçada, processos nos tribunais, recursos e direito intertemporal - vol. III. 49a ed. Rio de Janeiro: Forense, 2016.

TOMAZETTE, Marlon. Liberdade de associação e o recesso nas sociedades limitadas. Revista de Direito Brasileira, n. 1, p. 209-228, 2011.

ZAVASCKI, Teori Albino. Sentenças declaratórias, sentenças condenatórias e eficácia executiva dos julgados. Revista de Processo: RePro, São Paulo, v. 28, n. 109, jan./mar. 2003, p. 45-56. Disponível em: < https://bdjur.stj.jus.br/jspui/handle/2011/217>. Acesso em: 24 ago. 2017. 


\section{DADOS DA PUBLICAÇÃO}

Categoria: artigo submetido ao double-blind review.

Recebido em: 23/09/2017.

Aceito em: 06/09/2018. 
